\title{
CITRA PERUSAHAAN DALAM TAYANGAN ACARA TELEVISI LOKAL
}

\author{
Donny Perdana de Keizer \\ Jurusan Marketing Communication, Fakultas Komunikasi dan Multimedia, \\ Bina Nusantara University, Jln. K.H. Syahdan No. 9, Palmerah Jakarta Barat 11480
}

\begin{abstract}
This paper is about effectiveness imaging event through shows in television local, TVRI Yogyakarta, as government television media main based in Yogyakarta. Limited national budget as TVRI Yogyakarta's only capital to hold productions in addition to government regulation and limited commercial productions, urges managers to be more creative in creating cooperation chances due to increase income. TVRI, which now as Public Broadcasting Organization, serves public interest with allocated budget by the Nation. Producers' creativity determines the amount of show sponsors support. There are many ways to maximize its income as a part of imaging in the community. The imaging is not just through advertisement or public service announcement, but also through picture, logo, and sound.
\end{abstract}

Keywords: TVRI Yogyakarta, imaging

\begin{abstract}
ABSTRAK
Tulisan ini ingin mengupas tentang efektivitas kegiatan pencitraan lewat tayangan acara di stasiun televisi lokal. TVRI Yogyakarta, sebagai media televisi pemerintah yang berbasis lokal di kota Yogyakarta. Keterbatasan anggaran APBN sebagai modal TVRI Yogyakarta untuk menyelenggarakan produksi acaranya ditambah dengan regulasi pemerintah yang membatasi tayangan komersil di stasiun televisi ini membuat pengelola stasiun televisi harus kreatif dalam menciptakan peluang kerjasama yang bermuara pada peningkatan sumber pemasukan. Status TVRI, yang kini menjadi Lembaga Penyiaran Publik, semakin mengukuhkan lembaga ini untuk melayani kepentingan publik dengan anggaran yang dialokasikan oleh Negara. Kreativitas pembuat acara sangat menentukan sedikit banyaknya dukungan pihak sponsor acara. Berbagai cara dapat dilakukan untuk memaksimalkan pemasukan lembaga dengan menciptakan peluang yang dapat dimanfaatkan oleh sponsor sebagai bagian dari upaya pencitraan di masyarakat. Pencitraan tersebut tidak saja dilakukan melalui penayangan iklan atau pesan layanan masyarakat namun dapat juga melalui tayangan gambar logo dan suara yang diyakini memiliki kekuatan tersendiri bagi pemasang iklan.
\end{abstract}

Kata kunci: TVRI Yogyakarta, pencitraan 


\section{PENDAHULUAN}

Telah menjadi suatu pemahaman yang umum bahwa masalah penting yang dihadapi oleh lembga-lembaga sosial serta politik, setelah terjadinya revolusi indutri adalah masalah hubungan (relationship), yaitu bagaimana membangun dan mengembangkan hubungan-hubungan yang baik antara berbagai lembaga tersebut dengan masyarakat(publik). Demi tercapainya tujuan dari lembaga atau organisasi dengan publik yang erat, maka di butuhkan adanya hubungan yang dilandasi sikap saling percaya demi pemenuhan kebutuhan fisik, material maupun spiritual.

Kondisi dan iklim sosial di mana segenap lembaga tersebut bergerak, banyak di warnai kesalahpahaman, bahkan tidak menutup kemungkinan kadang-kadang di sertai dengan pertentangan secara terbuka antara atasan dan bawahan, antara pemilik saham dan pemimpin perusahaan, antara produsen dan komsumen atau pemakai jasa, antara industri dan masyarakat sekitarnya, serta antara publik dan distributornya. Inti permasalahannya adalah bagaimana dapat dicapai pendekatan dan penyesuaian sikap serta masyarakat terhadap lembaga-lembaga tersebut. Dengan tumbuhnya kesadaran akan pentingnya hubungan antara perusahaan dengan kelompok-kelompok masyarakat, saat ini manajemen perusahaan banyak memberikan perhatian kepada masalah-masalah kemasyarakatan dengan tujuan supaya segenap iklim usaha bisa berkembang dengan baik.

Dalam hal ini pemerintah dan lembaga-lembaga swasta telah memanfaatkan perkembangan ilmu pengetahuan dan teknologi serta ketrampilan public relation atau humas. Humas di lembagalembaga pemerintah maupun swasta merupakan salah satu fungsi manajemen dan sebagai alat manajemen. Peranan Humas di sektor swasta dengan struktur organisasi yang lebih luwes memberinya kesempatan yang lebih besar untuk bertindak sesuai dengan fungsinya. Sedangkan organisasi humas pada lembaga pemerintah berfungsi sebagai filter atau penyaring terhadap komunikasi timbal balik dengan tujuan menciptakan stabilitas umum. Tetapi secara garis besar, baik humas di sektor swasta maupun pemerintah mempunyai tujuan yang sama, yaitu untuk menciptakan iklim pendapat umum yang menguntungkan.

Kegiatan humas meliputi kegiatan pembenahan organisasi itu sendiri (PR begin at home) hingga kegiatan yang bersifat image building, yakni memberika citra organisasi yang baik atau positif pada masyarakat umum. Humas menyelenggarakan komunikasi timbal balik antara organisasi/ lembaga dengan publiknya untuk menciptakan salin perhatian (publik understanding) dan dukungan (support) demi tercapainya tujuan, kebijakan dan langkah serta tindakan lembaga. Oleh karena itu didalam menjalankan kegiatannya, humas tidak hanya dilakukan sambil lalu, melainkan melalukan semua kegiatan komunikasi guna mendorong daya pengaruh untuk menanamkan citra tertentu pada obyeknya. Tujuan strategis dari kegiatan ini adalah mencegah timbulnya konflik, meredakan atau menghilangkan konflik itu. Adapun sasaran strategisnya adalah terbantuknya salin pengertian yang saling memadai antara subyek (organisasi/lembaga perusahaan) dan obyeknya (publik).

Citra dalam diri publik merupakan hal esensial untuk di perhatikan oleh organisasi. Sejarah memperlihatkan bahwa opini publik mempunyai kekuatan laur biasa dalam segala bidang kehidupan. Pemerintah, parpol, perusahaan,yayasan, bisa dibangun dan tumbuh besar karena citra yang baik dari publik, dan sebaliknya bisa tumbang karena citra yang negatif.

Sementara itu salah satu media komunikasi yang dapat digunakan dalam rangka kegiatan humas adalah melalui media siaran (radio dan televisi) yaitu dengan kegiatan periklanan. Dengan sebuah iklan, orang akan mempunyai kesan tertentu. Dalam hal ini pemasangan iklan akan selalu berusaha untuk menciptaka iklan sebaik-baiknya. Misalnya dengan warna, ilustrasi dan bentuk lay out ysng menarik. Kadang-kadang pembeli sebuah barang tertentu dilakukan secara tidak rasional, tetapi lebih cenderung untuk meningkatkan gensi . Namun dari segi lain periklanan juga dapat menciptakan kesan pada masyarakat untuk melakukan pembeliansecara rasional dan ekonomis. Iklan yang di 
kampanyakan oleh humas tertentu saja berbeda dengan kegiatan iklam pada umumnya yang berorientasi pada pemasaran produk. Bila iklan biasa bermaksud merangsang pembelian oleh konsumen serta berbicara tentang produk-produk spesifik (merek tertentu), maka iklan yang dilakukan humas lebih memfokuskan diri pada kesan umum yang hendak dihadapi. Iklan yang dikampanyekan oleh humas inilah yang biasa dikenal dengan iklan korporat (coorporate advertising).

\section{PEMBAHASAN}

\section{Iklan dan Kegiatan Periklanan}

Iklan biasanya ditujukan untuk mendorong konsumen untuk membeli suatu produk. Namun demikian, hasil riset terhadap perilaku konsumen bersedia membeli. Salah satu diantaranya adalah reputasi dan citra produsen. Hal inilah yang mendorong beberapa perusahaan untuk melakukan kegiatan periklanan dalam bentuk iklan korporat melalui berbagai media yang ada.

Era milenium ketiga ditandai dengan adanya kemajuan teknologi di berbagai bidang. Salah satu yang mengalami perkembangan cukup pesat adalah teknologi komunikasi melalui saran televisi. Di Indonesia kemajuan ini ditunjukan dengan adanya peningkatan jumlah stasiun televisi terutama stasiun televisi swasta. Selama periode 10 tahun terakhir telah marak stasiun televisi swasta yang turut meramaikan dunia pertelevisian di tanah air di samping TVRI sebagai stasiun televisi pemerintah. Kondisi ini tentu saja mempunyai dampak positif bagi kemajuan pengetahuan dan proses adopsi inovasi teknologi di kalangan pemirsa yang dalam hal ini adalah warga masyarakat indonesia. Masyarakat menjadi memiliki banyak pilihan terhadap informasi yang dibutuhkan melalui sajian acara yang ditawarka masing-masing stasiun televisi. Hal ini tentu saja akan membantu memperkecil jarak kesenjangan pengetahuan dan perkembangan teknologi bangsa kita dengan bangsa-bangsa lain di dunia yang selama in telah menimggalkan kita.

Adanya fenomena tersebut, telah menyebabkan terjadinya pergeseran dalam hal fungsi televisi. Apabila sebelumnya, televisi yang pada waktu itu dimonopoli oleh stasiun televisi pemerintah (TVRI) hanya berfungsi sebagai sarana penyampaian informasi dan sarana hiburan maka semenjak munculnya stasiun televisi swasta telah mengalami pergeseran menjadi fungsi bisnis. Artinya siaran televisi tidak hamya sekedar penyampaian informasi dan pemberian hiburan bagi masyarakat, tetapi lebih dari itu adalah sarana untuk mengembangkan bisnis dan usaha ekonomi produktif melalui sarana periklanan dan promosi. Dapat kita lihat sekarang, hampir setiap waktu di sela-sela acara TV swasta selalu disajikan pesan-pesan iklan dari perusahaan sponsor acara tersebut. Sementara TVRI saat ini menjadi Lembaga Penyiaran Publik yang sebagian besar anggaran operasionalnya merupakan anggaran APBN yang disubsidi pemerintah.

Kenyataan ini tentu saja menimbulkan dilema sendiri bagi TVRI. Di satu sisi TVRI dituntut untuk menjadi sarana alat penyampai informasi pemerintah dengan tetap mampu merebut perhatian pemirsa, tetapi di sisi lain TVRI harus bersaing dengan stasiun-stasiun televisi swasta yang mana dari segi lain TVRI untuk dapat menyajikan acara yang benar-benar berkualitas dan mampu merebut perhatian pemirsa. Hal in yang menyebabkan TVRI mulai dijauhi pemirsa. Dampak paling nyata atas kondisi tersebut adalah rendahnya pemahaman masyarakat terhadap produk acara yang ditayangkan oleh TVRI itu sendiri.

\section{TVRI Yogyakarta sebagai Media Lokal}

Masalah tersebut juga dihadapi oleh TVRI Yogyakarta, yang dengan dukungan sarana dan modal yang terbatas dituntut untuk tetap profesional dan mampu bersaing dalam merebut perhatian pemirsa dangan stasiun swasta yang siarannya telah menjangkau wilayah tersebut. Meski dituntut 
untuk tetap berkembang dalam kondisi yang terbatas, TVRI Stasiun Yogyakarta ternyata mampu mampu menujukan profesionalitasnya.hal ini terlihat dengan adanya beberapa acara yang sampai saat ini masih menduduki perhatian pemisa yang cukup tinggi untuk acara televisi di Yogyakarta yang diproduksdi oleh TVRI Stasiun Yogyakarta diantaranya adalah (1) acara TV-Cafe, ditayangkan setiap Minggu, pada minggu ketiga pukul 19.90-20.30 WIB; (2) acara Ketoprak, ditayangkan setiap hari Selasa pukul 19.30-20.30 WIB; (3) acara Obrolan Angkring, ditayangkan setiap hari Jumat pukul 20.00-21.00 WIB; (4) acara Kuis Griya Gita, ditayangkan setiap hari Sabtu pada minggu ketiga pukul 20.00-21.00WIB.

Dari beberapa acara yang memiliki peringkat tersebut, acara TV Cafe merupakan acara yang paling diunggulkan. Inilah satu-satunya acara yang dimiliki oleh TVRI Stasiun Yogyakarta yang sampai saat ini menerima promosi iklan (meskipun tak langsung). Acara TV Cafe merupakan acara yang masuk dalam jenis tayangan musik. Acara ini disiarkan secara langsung dr studio II TVRI Yogyakarta, yang studio nya di setting/didekorasi menjadi satu cafe. Jenis musik yang ditampilkan meliputi musik jazz, rok 'n roll, pop, slow rock, maupun musik-musik nostalgia, yang penayangannya tentu saja tergantung pada tema musik yang diangkat. Melalui acara ini seorang pemirsa dapat meminta suatu lagu tertentu agar dinyanyikan, dengan memesan lewat telpon secar langsung.

Melalui penyusunan paket program seperti acara TV Cafe, ternyata telah mampu merebut perhatian dari sejumlah pemirsa baik dari kalangan muda maupun kalangan orang tua. Hal ini diketahui dari jumlah tamu yang hadir di studio maupun jumlah penelepon yang masuk. Berdasarkan data pra survey diketahui baha acara TV Cafe ini telah mampu merebut perhatian pemirsa.

Kualitas yang baik acara TV Cafe yang di sajikan TVRI Stasiun Yogyakarta, selain dibuktikan dengan pencapiannya rating yang tinggi dalam hal pemirsa, juga dapat dilihat kesediaan pihak sponsor untuk mendukung acara ini. Selama 2 tahun usia acara tersebut, ternyata telah mampu menumbuhkan motivasi yang tinggi dikalangan perusahaan untuk turut mendukung acara dengan penyediaan sponsor, terlihatdengan begitu banyaknya perusahaanyang selalu bersedia mensponsori acara tersebut. Beberapa perusahaan yang selama ini selalu mendukung acara tersebut adalah (1) Amigo Fashion, sebuah perusahaan toko pakaian; (2) PO Maju Lancar, sebuah perusahaan autobis; (3) Gurat Ungu Decoration, sebuah perusahaan jasa seni dekorasi; (4) Mad Flash Sound System, sebuah perusahaan jasa sewa sound system; (5) Bank BPD Daerah Istimewa Yogyakarta; dan (6) PT. Telkom.

Penyampaian pesan sponsor selain dilakukan secara langsung dalam bentuk iklan Televisi atau TVC, dapat juga dilakukan dengan mekanisme produk/jasa diucapkan (di-announce) oleh MC atau pembawa acara dan tulisan atau titling ucapan terima kasih pada pihak sponsor. Mengamati hal tersebut terdapat hal yang menarik, dimana meskipun kegiatan periklanan yang dilakukan oleh beberapa perusahaan sponsor pada acara TV Cafe tidak dilakukan secara langsung ternyata hal tersebut tidak menurunkan minat dan keinginan dari perusahaan sponsor untuk tetap mengiklankan produknya melalui acar TV Cafe di TVRI Stasiun Yogyakarta tersebut, meskupun terdapat media lainnya yang juga memungkinkan untuk dijadikan saran pengiklanan. Hal ini juga menunjukan bahwa perusahaan yang memasang iklan melalui acara TV Cafe di TVRI Stasiun Yogyakarta memperoleh keuntungan yang berarti maka tidak mungkin suatu perusahaan memasang iklan secara terus menerus.

Hubungan antara perusahaan atau suatu organisasi dan konsumennya sering dilakukan dengan menggunakan iklan. Secara tradisional, iklan didefinisikan pesan yang menawarkan suatu produk yang ditujukan kepada masyarakat lewat suatu media. Namun demikian, untuk membedakannya dari pengumuman biasa, iklan lebih diarahkan untuk mebujuk orang supaya membeli. Seperti dikemukakan oleh Frank F. Jefkins: advertising to persuade people to buy. Selanjutnya yang jadi pertanyaan adalah, bisakah iklan dipakai untuk kegiatan Public Relation (humas)? Jawaban dari pertanyaan ini tentu saja adalah bisa, hal ini karna iklan dapat dikemas sedemikian rupa sehingga tidak memaksa konsumen untuk membeli secara langsung, sementara itu kalau perusahaan berhasil membangun citranya lewat ikaln tertentu saja hal ini akan dapat menjanjikan kedatangan konsumen. 
Iklan yang dilakukan oleh humas tentu saja berbeda orientasinya dengan iklan yang biasa, dimana iklan yang biasa pada umumnya digunakan oleh produsen untuk memperkenalkan suatu produk, sementar iklan yang dilakukan oleh humas biasanya tidak di tujukan untuk membujuk orang secar langsung untuk membeli. Iklan-iklan inilah yang biasa dikenal dengan iklan korporat (coorporate advertising).

Mengenai iklan korporat ini sendiri terdapat empat jenis yaitu meliputi public relation advertising, institusional advertising, coorporate indentity advertising, recruitment advertising. Pertama adalah public relation advertising, agak mirip dengan pengumuman karena ditujukan untuk memberi penjelasan. Bedanya dengan pengumumana biasa, iklan ini ditujukan untuk membentuk suatu citra atau opini tertentu. Kedua iklan institusi (institusional advertising), dimana iklan ini ditujukan untuk memperkuat citra perusahaan dan meningkatkan awarness. Umumnya iklan seperti ini dikembangkan oleh perusahaan besar yang menyisihkan anggaran yang cukup besar. Iklan institusi ini dapat dikaitkan dengan peristiwa-peristiwa di dalam perusahaan maupun di luar perusahaan, seperti ualng tahun perusahaan, ualng tahun kemerdekaan, acara peresmian, peristiwa pembanguna dan lainnya.

Ketiga adalah coorporate indentity advertising, digunakan untuk menanamkan logo baru perusahaan kepada masyarakat. Logo adalah identitas, dan identitas mengandung sejumlah makna. Dengan menjelaskan makna sebuah logo seperti sikap perusahaan, pelayanan, dan sejarah perusahaan, di harapkan dapat mempengaruhi opini masyarakat. Iklan ini muncul bersamaan dengan kampanye melalui tulisan-tulisan di media massa ketika perusahaan mengganti logonya. Bentuk yang terakhir adalah recruitment advertising, ditujukan untuk menarik dan menyeleksi karyawan atau manager baru. Bagi calon karyawan, iklan lowongan pekerjaan tetap merupakan hal penting dan selalu di sambut dengan antusias. Iklan perekrutan selalu menimbulkan keinginan calon karyawan, dan proses seleksi menjadi bahan pembicaraan yang menarik. Oleh karena itu, dengan adanya perekrutan, perusahaan mempunyai kesempatan untuk menjelaskan sesuatu kepada masyarakat, sekaligus mebangun citranya.

Iklan korporat akan sangat efektif bila secara de facto intern perusahaan siap untuk memenuhi janjinya. Akan menjadi sia-sia apabila perusahaan bermaksud menutupi kelemahannya dengan iklan. Ini adalah suatu penyalahgunaan yang masih sering terjadi belakangan ini. Dengan lipstik mereka menanggap perusahaan akan lebih baik dari yang sebenarnya. Padahal wajah cantik akan kelihatan lebih buruk apabila tidak di dukung oleh kepribadian yang kuat dan budaya perusahaan. Penyalahgunaan konsep komunikasi dalam iklan perusahaan serimg tampil dalam bentuk-bentuk, yaitu menjanjikan citra pelayanan dan tidak dapat memenuhinya; menjanjikan posisi kepada calon karyawan sebagi manager, dengan fasilitas seperti mobil dan rumah, tetapi tidak dapat memenuhinya; menjanjikan sesuatu kepada masyarakat umum tetapi ternyata hal itu hanya berlaku pada kelompok tertentu saja.

Bentuk-bentuk penyalahgunaan ini hanyalah sebagian kecil dari ketidakmapuan praktisi humas di dalam perusahaan untuk mengendalikan fungsi-fungsi lain dalam perusahaan. Oleh karena itu selain perlu memahami ruang lingkup pekerjaan nya yang luas ini, seorang praktisi humas perlu mendapatkan dukungan dari pimpinan tertinggi perusahaan. Secara umum, kegiatan periklanan memang mempunyai banyak fungsi diantaranya adalah memberi informasi, membujuk atau mempengaruhi, menciptakan kesan (image), memuaskan keinginan, sebagai alat komunikasi.

Pertama, periklanan berfungsi untuk memberi informasi, hal ini berarti bahwa periklanan dapat menambah nilai suatu barang dengan memberikan informasi kepada kosumen. Nilai yang dicptakan oleh periklanan di sebut faedah informasi. Tanpa adanya informasi, orang segan dan tidak akan mengetahui banyak tentang suatu barang. Kedua, periklanan berfungsi untuk membujuk atau mempengaruhi, hal ini bearti periklanan tidak hanya bersifat memberitahu saja tetapi bersifat mebujuk terutama kepada pembeli-pembeli potensial dengan megatakan bahwa dengan sutau produk adalah lebih baik dari produk yang lain. Ketiga, periklanan berfungsi untuk menciptakan kesan (image), hal 
ini berati bahwa dengan sebuah iklan maka orang akan mempunyai kesan tertentu. Dalam hal ini pemasangan iklan akan selalu berusaha untuk menciptakan iklan sebaik-baiknya. Misalnya dengan warna, ilustrasi, bentuk lay out yang menarik. Kadang-kadang pembeli suatu barang tertentu dilakukan tidak secara rasional, tetapi lebih cenderung untuk meningkatkan gengsi. Keempat, periklanan berfungsi untuk memuaskan pembeli, dimana sebelum memilih dan membeli produk, kadang-kadang orang ingin diberitahu tentang tersebut dan bagaimana keadaan barang-barang tersebut. Jadi periklanan suatu alat yang dapat dipakai untuk mencapai tujuan peryukaran yang memuaskan. Kelima, periklanan berfungsi sebagai alat komunikasi, dimana periklanan merupakan suatu alat untuk membuka komunikasi dua arah antara penjual dan pembeli, sehingga keinginan mereka terpenuhi secara efektif dan efisien.

Terlepas dari jenisnya, apakah itu iklan korporat maupun iklan yang biasa, perusahaan melakukan kegiatan perikalanan tentunya mempunyai tujuan-tujuan tertentu. Tanpa adanya tujuan yang ingin dicapai maka tidak mungkin suatu perusahaan bersedia mengeluarkan biaya yang besar hanya untuk kegiatan periklanan. Secara umum tujuan dari kegiatan periklana adalah untuk meningkatkan penjualan yg menguntungkan. Namun demikian, terdapat beberapa tujuan yang ingin dicapai tersebut diantaranya adalah mendukung promosi personal selling dan kegiatan promosi itu; mencapai orang yang tidak dapat dicapai oleh tenaga penjualan dalam jangka waktu tertentu; memeperbaiki hubungan dengan para penyalur, misal dengan mencantumkan nama dan alamatnya; memasuki daerah pemasaran baru atau menarik pelanggan baru; memperkenalkan produk baru; mengubah penjualan industri; mencegah timbulnya barang-barang tiruan; memperbaiki reputasi perusahaan dengan memberikan pelayanan umum melalui periklanan.

Dalam melakukan kegiatan periklanan, manajemen dihadapkan pada masalah pemilihan media yang ingin di pakai. Hal ini penting karena tidak semua media yang ada selalu di gunakan. Agar supaya pemasangan iklan dapat memenuhi sasaran yang tepat denagan biaya yang efisien, maka perusahaan harus memilih media yang dianggapnya aplin tepat untuk mengiklankan produknya. Mengenai faktor-faktor yang menentukan pemilihan terhadap media periklana, menurut Basu Swastha adalah sebagai berikut:

\section{Tujuan Periklanan}

Dari beberapa tujuan periklanan yang ada, apabila perusahaan mengutamakan kecepatan sampainya berita kepada masyarakat atau pasar (dalam waktu relatif pendek) maka untuk mencapai tujuan tersebut aka lebih tepat bila perusahaan menggunakan radio atau surat kabar sebagai media periklanannya.

\section{Sirkulasi Media}

Sirkulasi media yang akan dipakai harus sesuai atau seluas distribusi produknya, baik secara geografis maupun distribusi pada segmen pasar yang di tuju.

\section{Keperluan Berita}

Ada beberap produk yang di dalam periklananya memerlukan gambar. Untuk maksud tersebut perusahaan dapat memilih media surat kabar, majalah, televisi atau slide di bioskop.

\section{Waktu dan Lokasi}

Waktu dan lokasi keputusan membeli dibuat. Dalam memilih media, perusahaan akan berusaha menjangkau konsumen, dalam suasana pemilihan alternatif keputusan untuk melaukan pembelian terhadap suatu produk. Keputusan yang diambil oleh konsimen tidak selalu terjadi di ruamh, tetapi dapat terjadi di jalan, di kantor, atau di tempat lain. 


\section{Biaya Advertising}

Pertimbangan biaya advertising dihubungkan dengan sejumlah dana yang tersedia dan sirkulasi media yang akan digunakan. Makin luas sirkulasi media tersebut, baiaya semakin tinggi namun diikutidengan semakin banyaknya pembaca atau pedengar, maka diharapkan jumlah pembeli semakin besar.

\section{Kerjasama dan Promosi}

Kerjasama dan bantuan promosi yang ditawarkan oleh media. Pada umumnya manajemen lebih condong untuk lebih memilih media yang baik dan memberikan bantuan promosi yang lebih besar.

\section{Karakteristik media}

Tidak semua produk dapat diiklankan melaui media yang sama. Maka sangat perlu mengadakan pemiliham media yang sesuai dengan sifat produknya.

\section{Media}

Kebaikan dan keburukan media penting untuk mempertimbangakan agar tercapai keefektifan biaya. Kegiatan periklanan pada umumnnya diguanakan oleh produsen untuk merangsang penjualan. Namun demikian sebenarnya juga mempunyai manfaat lain. Sebagaimana yang dikemukakan oleh Rhenald Kasali bahwa selain untuk merangsang penjualan, iklan juga dapat dipakai untuk mengangkat citra perusahaan. Bahkan iklan dapat di pakai untuk mengangkat citra perusahaan. Bahkan iklan dapat di pakai dapai dipakai untuk menjelaskan perilaku perusahaan pada konsumen dan khalayak nonkonsumen. Lebih jauh di katakan bahwa iklan dpat mempengaruhi opini publik. Kondisi inlah yang menyebabkan banyak perusahaan bersedia mengeluarkan biaya yang besar untuk melakukan kegiatan periklanan dengan maksud untuk membangun citra yang baik pada diri publik. Dengan tertanamnya citra (image) yang baik pada publik, perusahaan dapat tumbuh menjadi besar dalam lingkungan industri yang kondusif; karena adanya dukungan, pengertian, dan kepercayaan dari publik atau komunitas.

Sementara itu mengenai pengertian dari citra menurut David A. Aaker dan John G. Myers mengidentifikasikan sebagai :seperangkat anggapan, impresi, atau gambaran seseorang atau sekelompok orang mengenai obyek tertentu. Selanjutnya mengenai pengertian dari citra perusahaan itu sendiri, Claude Robinson \& Walter Barlow memberikan definisi sebagai: "Citra perusahaan merupakan gambaran mental yang ada di benak khalayak tentang perusahaan, gambaran mental ini mungkin diperoleh dari pengalaman langsung maupun tidak langsung. Mungkin rasional atau irrasional, tergantung pada keterangan atau isu yang tampak pada pola yang tak terbatas.”

Untuk membentuk citra (image)publik terhadap perusahaan atau lembaga bukan hal yang sederhana dan mudah. Pembentukan citra melalui serangkaian proses yang panjang, mulai proses seleksi dan interpretasi. Dalam proses penyampaian pesan terhadap khayalak, gar khalayak dapat menerima gagasan/pesan yang di sampikan maka pesan tersebut harus mendapatkan perhatian dari pihak khalayak. Merebut perhatian khalayak terhadap pesan yang disampaikan adalah hal yang tidak mudah dalam dunia usaha. Khalayak dihadapkan pada beribu pesan yang harus mereka seleksi untuk menerimanya. Karena dalam menghasilkan pesan senantiasas melibatkan sumberdaya, baik biaya, pemikiran, maupun waktu, maka seorang komunikator harus mengerti bagaimana atensi itu bekerja, faktor-faktor apa saja yang mendukung maupun menghambat pembentukan atensi menurut De Lozier adalah proses mental dari pemusatan secara sadar dari rangsangan yang di berikan. 
Proses lanjut kemudian yang terdekat dengan atensi dalam pembentukan citra khalayak dalah persepsi. Persepsi adalah proses memberi makna sehingga di peroleh pengetahuan baru. Proses persepsi dari khalayak telah terjadi setealah mereka memperoleh informasi baik melalui sluran tatap muka maupun terpaan media.

Pesan akan diterima khalayak setelah melaui seleksi dan interprestasi, yang akhirnya akan membentuk citra. Sebagaimana yang sudah dikemukakan oleh De Lozier bahwa persepsi adlah proses pembentukan citra atau kesan dari suatu rangsangan (stimulus) yang melibatkan seleksi dan interprestasi dari masukan-masukan melalui panca indra.

Dalam kegiatan periklanan, teori image building dapat di deskripsikan bahwa stimuli dapat berwujud pesan-pesan atau infomasi kepada pemirsa di studio tentang produk-produk perusahaan pemasangan iklan yang diiklankan pada acara TV Cafe di TVRI Stasiun Yogyakarta; Cara penyampaian pesan-pesan atau informasi kepada pemirsa di studio tentang produk-produk perusahaan pemasangan iklan yang di iklankan di TV Cafe di TVRI Stasiun Yogyakarta; kebenaran pesan-pesan atau informasi kepada pemirsa di studio tentang produk-produk perusahaan pemasangan iklan yang di iklankan di acara TV Cafe di TVRI Stasiun Yogyakarta.

Selanjutnya stimuli-stimuli tersebut ditangkap secara fisik oleh panca indera pemirsa di studio. Selamjutnya pada diri pemirsa di studio akan terjadi proses komunikasi intra personal yang ileh Schramm didefinisikan sebagai kominukasi dangan diri sendiri atau proses berfikir khususnya menimbang untung rugi usul yang disampaikan oleh pihak komunikator. Dalam proses ini akan terjadi proses seleksi dalam diri pemirsa acara TV Cafe di studio TVRI Stasiun Yogyakarta.

Dalam seleksi pesan ini akan terjadi serangkaiana proses seleksi perhatian dan seleksi persptual yang melibatkan panca indera secara keseluruhan. Seleksie perhatian terjadi karena banyak faktor yang dapat mempengaruhi derjat perhatian pengunjung pada stimuli; sehingga tidak semua stimuli atau informasi yang disampaikan akan mendapat perhatian yang sama dari setiap pemirsa. Perhatian disini dapat diartikan sebagai proses mental ketika stimuli atau rangkaian stimuli meninjol dalam keadaan pada saat stimuli yang lain melemah.

Selektifitas perseptual terjadi karen suatu situasi secara potensial menyajikan informasi yang tidak mungkin semua terserap oleh manusia. Seleksi perseptual adalah proses penyerapan informasi yang disajikan oleh suatu situasi denganhanya memperhatikan bagian-bagian informasi yang dipilih individu. Oleh karena itu informasi dan stimuli-stimuli lain yang di peroleh selama menyaksikan acara TV Cafe sangat luas, sementara itu pengunjung mempunyai keterbatasan-keterbatasan, maka selejtifitas perseptual tidak bisa dihindarkan. Sebagian informasi dan stimuli lain yang tersedia mendapat perhatian sepenuhnya, sebagian mendapat perhatain secara tidak langsung dan sebagian lain sama sekali luput dari perhatian.

Proses ini berlanjut dengan penerimaaan dan pemahamana informasi oleh pengunjung (perceiving). Proses penerimaan atau pemahaman atau perceivimg adalah proses pencocokan, penyeleksi, pengintensifikasian, pengkonserbttasian danpengintergrsian dengan tanggapan-tanggapan sebelumnya yang telah ada pada kita. Setelah stimuli dipahami oleh pengunjung, akan tumbuh persepsi dalam diri pengunjung tentang perusahaan yang melakukan kegiatan periklanan.dengan mengutib Descrado, Jalaludin Rahcmat memberikan definisi persepsi sebagai pengalaman tentang obyek, peristiwa atau hubungan-hubungan yang di peroleh dengan menyimpulkan informasi dan menafsirkan pesan. Selanjutnya dalam diri pemirsa yang ada di studio akan muncul anggapa-anggapan dan kesimpulan-kesimpulan tentang perusahaan yang melakukan kegiatan dengan segal produk yang ditawarkan. 


\section{SIMPULAN}

Rangkaian proses tersebut akhirnya bermuara pada tertanamnya citra atau image dalam diri pemirsa di studio pada acara TV Cafe di TVRI Stasiun Yogyakarta. Sementara itu, analisis citra perusahaan, Claire mengungkapkan beberapa atribut yang dapat dipakai, antara lain, kualitas amanjemen, kualitas barang dan jasa, kegiatan inovatif dan kesehatan keuangan. Dengan mengacu pendapat ini maka selanjutnya citra pemirsa di studio terhadap perusahaan pemasang iklan pada acara TV Cafe di TVRI Stasiun Yogyakarta ini dapat di lihat dari kesan dan penilaian pemirsa terhadap kualitas barang dan jasa yang di tawarkan oleh perusahaan pemasang iklan pada acara TV Cafe di TVRI Stasiun Yogyakarta; kesan dan penilaian pemirsa terhadap harga barang dan jasa yang ditawarkan oleh perusahaan pemasang iklan pada acara TV Cafe di TVRI Stasiun Yogyakarta; kesan dan penilaian pemirsa terhadap inovasi dari barang dan jasa yang di tawarkan pemasang iklan pada acara TV Cafe di TVRI Stasiun Yogyakarta; kesan dan penilaian pemirsa terhadap tanggung jawab terhadap komunitas dan lingkungan dari perusahaan pemasang iklan pada acara TV Cafe di TVRI Stasiun Yogyakarta.

\section{DAFTAR PUSTAKA}

Anonim (2004). HUMAS Membangun Citra Dengan Komunikasi. Bandung: PT. Remaja Rosda Karya.

Gregory, A. (2004). Public Relations Dalam Praktek. edisi ke 2. Jakarta : Erlangga.

TVRI Yogyakarta. (1997). Selayang Pandang TVRI Yogyakarta. 